\title{
The relationship between pre-service science teachers' epistemological beliefs and preferences for creating a constructivist learning environment
}

\author{
Aslı Saylan, Fulya Öner Armağan, and Oktay Bektaş \\ Elementary Science Education, Erciyes University, Kayseri, Turkey \\ For correspondence: aslisaylan@erciyes.edu.tr
}

\begin{abstract}
The present study investigated the relationship between pre-service science teachers' epistemological beliefs and perceptions of a constructivist learning environment. The Turkish version of Constructivist Learning Environment Survey and Schommer's Epistemological Belief Questionnaire were administered to 531 pre-service science teachers attending seven public universities in Turkey. For data analysis, the Statistical Package for Social Sciences 20 program was used and correlation analysis was conducted to investigate the relationship between the participants' epistemological beliefs and perceptions of a constructivist learning environment. Also, descriptive analysis was conducted to determine their epistemological beliefs and perceptions of a constructivist learning environment. The results showed that the more sophisticated epistemological beliefs the participants have, the more constructivist learning environments they prefer, and positive/negative relationships were found among subscales of the two scales. Moreover, the results revealed that pre-service science teachers have relatively sophisticated epistemological beliefs, and generally prefer more constructivist learning environments. The implications were discussed.
\end{abstract}

Keywords: constructivist learning environment, epistemological beliefs, pre-service science teachers, science education

\section{Introduction}

Epistemological beliefs are beliefs regarding the nature of knowledge and learning (Elby \& Hammer, 2001; Schommer, 1990). Personal epistemology is students' beliefs about knowledge and knowing including some or all of the following: beliefs about the definition of knowledge, how knowledge is constructed, how knowledge is evaluated, where knowledge resides, and how knowing occurs (Hofer, 2001). According to Schommer (1990), personal epistemology is "a belief system that is composed of several more or less independent dimensions" (p.498). Schommer (1990) developed a 63 Likert-type item questionnaire named the Schommer Epistemological Questionnaire (SEQ) to determine learners' epistemological beliefs and identified five dimensions of epistemological beliefs. Table 1 indicates these dimensions.

Table 1. The dimensions of epistemological beliefs hypothesized by Schommer's (1990)

\begin{tabular}{ll}
\hline $\begin{array}{l}\text { Epistemological } \\
\text { Beliefs }\end{array}$ & Definition \\
\hline $\begin{array}{l}\text { Simple Knowledge } \\
\text { Omniscient Authority }\end{array}$ & $\begin{array}{l}\text { Knowledge is simple rather than complex. } \\
\text { Knowledge is handed down by authority rather than from reason and } \\
\text { empirical evidence. }\end{array}$ \\
$\begin{array}{l}\text { Certain Knowledge } \\
\text { Quick Learning }\end{array}$ & $\begin{array}{l}\text { Knowledge is unchanging rather than tentative. } \\
\text { Learning is quick or not at all. }\end{array}$ \\
Innate Ability & The ability to learn is innate rather than acquired.
\end{tabular}


Schommer (1990) stated that personal epistemology is multidimensional and students' beliefs concerning knowledge are related with five basic dimensions:

1. Source of knowledge: Knowledge is not handed down by omniscient authority and knowledge is also reasoned out through objective and subjective means. (Omniscient Authority)

2. Certainty of knowledge: Knowledge is not absolute and knowledge is constantly evolving. (Certain Knowledge)

3. Organization of knowledge: From knowledge is compartmentalized to knowledge is highly integrated and interwoven. (Simple Knowledge)

4. Control of learning: From ability to learn is genetically predetermined to ability to learn is acquired through experience. (Fixed Ability)

5. Speed of learning: From learning is quick or not-at-all to learning is a gradual process. (Quick Learning)" (p. 499).

The results of the Schommer's study indicated that epistemological beliefs affect the students' processing of information and monitoring of their comprehension. There is a growing body of literature on personal epistemological beliefs today. There are many studies revealing that epistemological beliefs are important predictors in students' learning (Chan, 2004, 2011; Hofer \& Pintrich, 1997; Schommer, 1993; Tsai, 2000; Zeidler et al., 2003). For instance, Hofer and Pintrich (1997) stated that students' epistemological beliefs affect their learning outcomes. Also, the results of Schommer's (1993) study revealed that epistemological beliefs change as a function of students' perceptions of constructivist learning environments, and learning approaches. The development of learners' epistemological beliefs is influenced by the teacher's theories of teaching and the learners' perceptions of the learning environment and learning approaches (Sheppard \& Gilbert, 1991).

Constructivism is an important approach in science education (Taber, 2008). Constructivism is a philosophical belief that people construct their own understanding of reality (Jonassen, 1991; Oxford, 1997). In other words, the active learner builds his/her own knowledge in this approach. Constructivism puts major emphasis on the learning environment in order to develop the constructive process for introducing new scientific concepts (Lee \& Fraser, 2000; Limon, 2001). Wilson (1996) describes the learning environment as "a place where people can draw upon resources to make sense out of things and construct meaningful solutions to problems" (p.3). In a constructivist learning environment, teachers are facilitators who encourage their students towards conceptual development while students use their prior knowledge, reflect upon other students' ideas in the classroom and develop their conceptual understanding of new scientific topics (Yager, 1991; Y1lmaz-Tüzün \& Topçu, 2010). The learning environment includes two levels: (1) School level environment, (2) Class level environment. The school level environment is interested in educational administration, while the class level environment is interested in the teaching and learning environments of classrooms (Fraser \& Rentoul, 1982). Also Fraser and Rentoul (1982) suggested that classroom climate refers to the relationships between the teacher and students or among students while school climate refers to a teacher's relationships with other teachers, senior staff and the school principal. Thus, students' perceptions are generally used to measure classroom environment.

Many studies indicated that learners have some preferences for their learning environments (Aldridge et al., 2000; Johnson \& McClure, 2004). These preferences represent how learning occurs and what the factors affect learners' learning. In other words, if the learners perceive their learning environments positively, they can learn better. The constructivist perspective suggests that learners are the co-constructors of knowledge and the constructivist learning environment is very important to promote meaningful learning (Lee \& Fraser, 2000). Starting from this point of view, the present study examines the classroom environment in terms of pre-service science teachers' preferences for creating a constructivist learning environment. In other words, this study also investigates the constructivist learning environment from five different perspectives by using CLES. These perspectives are defined in Table 2. 
Table 2. Five subscales of CLES

\begin{tabular}{|c|c|}
\hline Subscales & Definition \\
\hline $\begin{array}{l}\text { Learning about the } \\
\text { world }\end{array}$ & $\begin{array}{l}\text { The extent to which school science and students' daily life experiences are } \\
\text { related }\end{array}$ \\
\hline Learning about science & $\begin{array}{l}\text { The extent to which students learn the properties of science such as } \\
\text { subjectivity }\end{array}$ \\
\hline Learning to speak out & $\begin{array}{l}\text { The extent to which students have the right to question the teacher about } \\
\text { some classroom affairs }\end{array}$ \\
\hline Learning to learn & The extent to which students are responsible for their learning \\
\hline $\begin{array}{l}\text { Learning to } \\
\text { communicate }\end{array}$ & The extent to which students' negotiation is allowed \\
\hline
\end{tabular}

Adapted from Taylor and Fraser (1991).

Constructivist conceptions of learning assume that knowledge is individually constructed and socially co-constructed by students on the basis of their interpretations of experiences in the world (Jonassen, 1999). Likewise, constructivist learning environments are student-centered allowing students not only the opportunity to determine the learning activities but also to determine learning goals and regulate their own performance toward those goals (Liang \& Gabel, 2005). The implementation of constructivism is a very challenging process for teachers. Thus, Windschitl (2002) specified four dilemmas that teachers face in the implementation of constructivism: conceptual, pedagogical, political and cultural. The conceptual dilemma is concerned with teachers' understanding of what constructivism is and internalizing and reconciling that understanding with their own teaching belief systems. To overcome this dilemma, teachers need to reconcile their own beliefs about teaching, learning and knowledge - that is, their epistemology - with the underlying epistemological assumptions of constructivism.

Learning environment and personal epistemological beliefs have been a great concern for educators. Some of these studies have focused on the relationship between learning environments, especially the constructivist learning environment, and personal epistemological beliefs (e.g. Aypay, 2011; Chan, 2003; Tsai, 2000; Yılmaz-Tüzün \& Topçu, 2010). However, there is limited research investigating a possible relationship among pre-service science teachers' epistemological beliefs, conceptions about teaching and learning, and constructivist learning environment. In one of these studies, Tsai (2000) explored positive relationships between tenth-grade students' scientific epistemological beliefs and their preferences for constructivist learning environments. Tsai (2000) found that there were negative relationships between students' scientific epistemological belief orientations and their perceptions of actual learning environments. Additionally, Chan (2003) aimed to investigate the relationship between pre-service teachers' scientific epistemological beliefs and their conceptions about teaching and learning. In his study, it was found that the pre-service teachers who had constructivist conceptions of teaching and learning believed that knowledge is constructed from one's experiences and judgment; knowledge is tentative and changing; and ones' ability is not inborn, rather it can be changed. Yılmaz-Tüzün and Topçu (2010) investigated pre-service science teachers' epistemological beliefs, epistemological world views, and self-efficacy beliefs with respect to academic achievement and gender. They found that when individuals get scores of more than 2.5 points, they have less sophisticated epistemological beliefs. In another study, Aypay (2011) investigated the relationship between the teaching and learning conceptions and epistemological beliefs of pre-service teachers from different departments. In this study, it was found that there was a significant relationship between participants' epistemological beliefs and teaching-learning conceptions. Also, there were significant correlations between pre-service teachers' epistemological beliefs and teaching-learning approaches in this study. As another finding, Aypay (2011) stated that pre-service teachers preferred constructivist approach over the traditional approach.

In conclusion, the above-mentioned studies pointed out a positive relationship between pre-service science teachers' epistemological beliefs and preferences for creating a constructivist learning environment. However, the related literature mostly explored an overall relationship between these two concepts. Conceptual change can occur in the students' mind, when they change their 
epistemological beliefs. However, students need to develop the subdimensions of epistemological beliefs in order to reach successful conceptual change. In other words, students should extend or widen their epistemological beliefs for explaining the concepts, objects, and processes in their learning environment. Therefore, they must have suitable conditions to explore and discuss their views. If they build a suitable environment, the subdimensions of the epistemological beliefs of students may change from their own view to a scientific view (Taber, 2001). Hence, in the present study, the aim was to investigate the relationships among the subdimensions of pre-service science teachers' epistemological beliefs and the subdimensions of their preferences for creating a constructivist learning environment. For this reason, the main purpose of this study is to investigate whether there is a relationship between pre-service science teachers' epistemological beliefs and preferences for creating a constructivist learning environment or not. On this basis, our research question is: What is the relationship between pre-service science teachers' epistemological beliefs and preferences for creating a constructivist learning environment? The two sub-problems of this study are: (1) What are the epistemological beliefs of pre-service science teachers? (2) What are the preferences of pre-service science teachers for creating a constructivist learning environment?

\section{Method}

\section{Research design.}

The main aim of this study was to explore the relationship between pre-service science teachers' epistemological beliefs and preferences for creating a constructivist learning environment. In order to achieve this purpose, a correlational design was used in this study. Correlational studies investigate the relationships that may exist among two or more variables as well as their implications for cause and effect (Fraenkel \& Wallen, 2009).

\section{Sample.}

Fourth year pre-service science teachers (531) participated in the study. Since the perceptions and beliefs of learners change over time (Perry, 1970), data were collected in one semester from fourth year pre-service science teachers. The participants consisted of students from seven public universities which are located in Bolu, Kırşehir, Amasya, Kayseri, Ankara, Nigde and Sakarya. The numbers of students from these universities are given in Table 3 respectively. The target population of the study was all fourth year pre-service science teachers enrolled in these universities in the fall semester of 2014-2015. According to the information received from the student affairs departments of these universities, the target population of this study was about 750 pre-service science teachers. Moreover, convenience sampling was used in this study. Therefore, 531 pre-service science teachers participated to the study voluntarily. Thus, the sample of the study constitutes $70.8 \%$ of the target population. Likewise, 408 pre-service science teachers were males and 123 were females. The mean age of the sample was about 22 years. The demographic information of the participants is presented in Table 3.

Table 3. Demographic information of participants

\begin{tabular}{lllllll}
\hline \multicolumn{3}{c}{ Female } & \multicolumn{3}{c}{ Male } & \multicolumn{3}{c}{ Total } \\
\hline University & Number & $\%$ & Number & $\%$ & Number & $\%$ \\
\hline 1 & 37 & 78.7 & 10 & 21.3 & 47 & 8.9 \\
2 & 17 & 85.0 & 3 & 15.0 & 20 & 3.8 \\
3 & 77 & 72.6 & 29 & 27.4 & 106 & 20.0 \\
4 & 70 & 76.9 & 21 & 23.1 & 91 & 17.1 \\
5 & 121 & 76.6 & 37 & 23.4 & 158 & 29.8 \\
6 & 45 & 70.3 & 19 & 29.7 & 64 & 12.1 \\
7 & 41 & 91.1 & 4 & 8.9 & 45 & 8.5 \\
Total & 408 & 76.8 & 123 & 23.2 & 531 & 100 \\
\hline
\end{tabular}




\section{Instrumentation.}

In this study, two instruments were applied to the participants respectively: (1) Schommer's Epistemological Questionnaire (SEQ) (Schommer, 1990), and (2) the Constructivist Learning Environment Survey (Taylor \& Fraser, 1991; Taylor et al., 1997). SEQ was used to assess pre-service science teachers' epistemological beliefs and CLES was applied to assess pre-service science teachers' preferences for creating a constructivist learning environment.

Schommer's Epistemological Questionnaire (SEQ).

In this study, SEQ, developed by Schommer (1990), was used to determine pre-service science teachers' epistemological beliefs. The questionnaire consists of 63 items that use a 5-point Likert scale ( $1=$ strongly disagree; $5=$ strongly agree). Items with a negative statement were reverse coded. Some sample items of SEQ are as follows:

- The most important part of scientific work is original thinking. (Simple knowledge)

- The only thing certain in life is uncertainty itself. (Certain knowledge)

- You can believe almost everything you read. (Omniscient authority)

- Some people are born to be good learners; others are stuck with a limited ability. (Innate ability)

- Learning is a slow process of building up knowledge. (Quick learning)

SEQ includes five hypothetical dimensions and 12 subscales within these dimensions (see Table 4). Schommer carried out numerous validation studies (Schommer, 1990, 1992, 1993). She found four factors reflecting the personal epistemological beliefs of individuals. These are simple knowledge, innate ability, quick learning, and certain knowledge. The factor of Omniscient Authority has not been found in Schommer's studies yet. The reliability analysis was conducted by Schommer (1993) and it was reported that inter-total item correlations ranges between .51 and .78.

Table 4. Hypothetical dimensions and subscales of SEQ

\begin{tabular}{llc}
\hline Hypothetical dimensions & Subscales & Number of items \\
\hline Simple knowledge & Seek single answers & 11 \\
Certain knowledge & Avoid integration & 8 \\
& Avoid ambiguity & 5 \\
Omniscient authority & Knowledge is certain & 6 \\
& Do not criticize authority & 6 \\
& Depend on authority & 4 \\
Innate ability & Cannot learn how to learn & 5 \\
& Success is unrelated to hard work & 4 \\
Quick learning & Ability to learn is innate & 4 \\
& Learning is quick & 5 \\
& Learn the first time & 3 \\
\hline
\end{tabular}

Adapted from Schommer's (1990) "Effects of beliefs about the nature of knowledge on comprehension" (p.500).

Schommer (1994) suggested that personal epistemological beliefs vary from 'naive' to 'sophisticated'. For instance, a person, who holds naive epistemological beliefs, believes that knowledge is simple, clear and specific. For this person, learning ability is innate and fixed, and can be transmitted directly to the students. However, a person, who holds sophisticated epistemological beliefs, believes that knowledge is complex, uncertain, tentative, and can only be gradually constructed by the learner. In SEQ, scores of more than 2.5 points indicate that learners possess less sophisticated (relatively naive) epistemological beliefs, whereas scores of less than 2.5 points indicate that learners have sophisticated epistemological beliefs (Yilmaz-Tüzün \& Topçu, 2013). Throughout the present study, the term naive was used to refer to pre-service science teachers who have a tendency to believe that truth is certain and simple and to transfer knowledge from an authority. The term sophisticated was used to refer to pre-service science teachers who have a tendency to believe that truth is relative, changing, and actively constructed by the individual (Kardash \& Scholes, 1996). 
Y1lmaz-Tüzün and Topçu (2008) translated and validated SEQ into Turkish. Researchers conducted a pilot study in which 94 pre-service science teachers participated. During the data analysis, researchers performed factor analysis. Factor analysis structures showed parallelism with Schommer's (1990) study. In this study, the translation into Turkish was performed by two Turkish experts. Then, the Turkish version was translated back into English and the orginal version and final English version were compared by bilingual experts in the field of epistemology in the USA (Yılmaz-Tüzün \& Topçu, 2008). SEQ was also piloted with 40 pre-service science teachers and similar results were obtained for factor analysis with Schommer's study. According to their study, four factors that account for 54.61\% of the variance were innate ability, simple knowledge, certain knowledge, and omniscient authority. They found the inter-total item reliabilities that compose each factor to be between .20 and .60.

Validation of SEQ. Firstly, the translated version was examined by three science education experts to ensure the content validity of SEQ used in this study. Then, the final form of SEQ was given. Secondly, the results of this study were compared with another study conducted by Author in 2014 to determine the criterion validity of SEQ. A moderate positive correlation $(r=.43, p=.02)$ was found between the total SEQ scores of the present study and that of Author (2014). Thirdly, on the basis of construct validity, factor analysis (FA) was conducted in order to validate and define the factor structure of the 12 subscales of the items of SEQ. The Kaiser-Meyer-Olkin (KMO) index and Bartlett's Test of Sphericity (BTS) were examined. The KMO index was .76 and BTS was 980.3 ( $p<.05)$. Based on these values, it was suitable to run FA. The results of FA revealed four factors that account for $55.9 \%$ of the variance.

Similar with Schommer's (1990) analyses, descriptive titles were given to each factor having factor loadings of .50 and higher. Hence, the first factor was named "Omniscient Authority". This factor included the subscale dimension of "cannot learn how to learn" and had the Cronbach's alpha coefficient of .58. The second factor was named "Innate Ability". This factor possessed the dimensions of "ability to learn is innate" and "learning is quick" and obtained the Cronbach's alpha coefficient of .57. The third factor was named "Simple Knowledge" and included the subscale dimension of "seek single answers". The Cronbach's alpha coefficient of this factor was .61. Finally, the last factor was named "Certain Knowledge" and included the subscale dimension of "avoid ambiguity". The Cronbach's alpha coefficient of this factor was .53. The reliability of the total survey including 63 items was found to be .71 as measured by the Cronbach's alpha coefficient.

Constructivist Learning Environment Survey (CLES).

The teacher preferred version of CLES was used in this study. The "preferred" indicates the participant' preferences for creating a learning environment in their future classroom. It was developed by Taylor et al. (1997) and adapted to Turkish by Aydin et al. (2012) for pre-service chemistry teachers. For the present study, the survey was adapted for pre-service science teachers by the researchers. The survey includes a 30-item 5-point Likert scale (never, seldom, sometimes, often, and always). It includes five subscales: (1) Learning about the world, (2) Learning about science, (3) Learning to speak out, (4) Learning to learn, and (5) Learning to communicate (see Table 5). Sample items of CLES are as follows:

- Students could learn how science can be part of their out-of-school lives. (Learning about the world)

- Students would learn that science has changed over time. (Learning about science)

- It was OK for students to ask me "why do I have to learn this?" (Learning to speak out)

- Students helped me to decide how well they are learning. (Learning to learn)

- Students talked with other students about how to solve problems. (Learning to communicate)

One of the purposes of this study is to determine pre-service science teachers' preferences for creating a learning environment in their future classes. Using CLES, students' perceptions were measured from five different perspectives. Since the theory used for the development of CLES and our understanding of a constructivist learning environment are parallel with each other, this instrument was selected to use in this study. 
Table 5. Subscales of Turkish version of CLES

\begin{tabular}{ll}
\hline Subscales & Items \\
\hline Learning about the World (Personal Relevance) & $1-6$ \\
Learning about Science (Uncertainty) & $7-12$ \\
Learning to Speak Out (Critical Voice) & $13-18$ \\
Learning to Leam (Shared Control) & $19-24$ \\
Learning to Communicate (Student Negotiation) & $25-30$ \\
\hline
\end{tabular}

Adapted from Aydin et al. (2012).

In the scope of the study of Aydin et al. (2012), the original version of CLES was adapted to Turkish independently by a bilingual researcher with a $\mathrm{PhD}$ in education. Then, the translated version of CLES was examined by three science education experts. The experts also checked the equivalence of both the translated and original versions of CLES. Then, the final version of the survey in Turkish was formed. In their study, Aydin et al. (2012) found the reliability of CLES was.87 overall; and the Cronbach's alpha coefficient.71 for learning about the world (LW), .71 for learning about science (LS), .84 for learning to speak out (LSO), .86 for learning to learn (LL), and .83 for learning to communicate (LC). Thus, CLES was found to be a reliable instrument. The reliability analysis of the present study (.89) supports the study of Aydın et al. (2012).

Validation of CLES. The translated version was examined by three science education experts to ensure the content validity of CLES used in this study. Then, the final form of CLES was given.

On the basis of construct validity, the exploratory factor analysis (EFA) was used in order to validate and define the factor structure of CLES items. For this purpose, the KMO and BTS were examined. The KMO index was .89 and BTS was $6625.3(\mathrm{p}<.05)$. Based on these values, it was suitable to run EFA. The EFA results revealed that there were six factors with Eigen values higher than 1 . However, since CLES has five factors originally, EFA was run again by fixing the factor number as five. In this manner, the results showed that item factor loadings were between .432 and .828 which means all of the factor loadings are larger than .40. Additionally, all items were loaded to the corresponding factor as in the original version of CLES. The results of EFA revealed five factors that account for $56.83 \%$ of the variance.

In the present study, after checking the normal distribution assumption, reliability analysis for CLES was conducted. The reliability of the total survey including 30 items was found to be .89 as measured by the Cronbach's alpha coefficient. The Cronbach's alpha coefficient was .87 for LW, .88 for LS, .87 for LSO, .79 for LL, and .68 for LC. Since all of the reliability coefficients were highly reliable, it might be concluded that CLES is a reliable instrument (Frankel \& Wallen, 2009).

\section{Data collection and analysis.}

Data collection and analysis process continued through the 2014-2015 fall semester. The instruments were applied during two weeks in November. The pre-service science teachers were given approximately 50 minutes to complete the two instruments, which were answered in the same class hour in the order of SEQ and CLES. An assistant helped with collecting data at each university by following the same procedure in each classroom to be sure about the consistency of data collection procedure.

The Statistical Package for Social Sciences (SPSS) 20 was used to analyze the data. Firstly, descriptive statistics were conducted to assess pre-service science teachers' epistemological beliefs and their preferences of CLE. Due to the reverse scoring, participants who got higher scores from the SEQ were seen as having less developed epistemological beliefs. As mentioned before, participants who had mean scores of less than 2.5 had sophisticated epistemological beliefs. Likewise, participants who got higher scores from the CLES preferred more constructivist learning environments. In other words, participants who had mean scores of more than 3.0 preferred more constructivist learning environments. Secondly, correlation analysis was conducted to explore the relationship between participants' epistemelogical beliefs and preferences of CLE. 


\section{Results}

Pre-service science teachers' epistemological beliefs.

The descriptive statistics results showed that participants had an average SEQ total score of 166.60. If all the participants choose " 3 " for each item on the questionnaire, their average expected SEQ total score will be 189.00. Hence, since the average SEQ total score (166.60) is lower than the expected SEQ total score (189.0), it can be concluded that the pre-service science teachers have relatively sophisticated epistemological beliefs.

The descriptive statistics results also showed that the participants had the highest mean score for item $19(\mathrm{M}=4.15)$ belonging to the simple knowledge subscale, and the lowest mean score for item 11 and item $31(\mathrm{M}=1.79)$ belonging to the simple knowledge subscale of SEQ. Accordingly, pre-service science teachers thought that teachers should be able to decide the best teaching method (item 19). Moreover, it was thought that a good teacher should not keep students from wondering about the right track (item 11), and being a successful student generally does not require memorization (item $31)$.

Pre-service science teachers' epistemological beliefs on the basis of subcales of SEQ.

Table 6 shows the pre-service science teachers' average scores and standard deviations for the subdimensions of SEQ. According to the descriptive statistics results, the pre-service science teachers had numerically different mean scores for the four subscales. The mean scores from highest to lowest were as follows: Certain Knowledge with an average of 3.17, Simple Knowledge with an average of 3.03, Innate Ability with an average of 2.63, and Omniscient Authority with an average of 2.11. The results revealed that students had sophisticated epistemological beliefs for omniscient authority because their scores were less than 2.5 .

Table 6. Pre-service science teachers' mean scores on subdimensions of SEQ

\begin{tabular}{llll}
\hline Dimension & $\mathrm{M}$ & $\mathrm{SD}$ & Range \\
\hline Omniscient Authority & 2.11 & & \\
Cannot learn how to learn & 2.11 & 0.56 & $1.00-5.00$ \\
Innate Ability & 2.63 & & \\
Ability to learn is innate & 2.72 & 0.71 & $1.00-5.00$ \\
Learning is quick & 2.54 & 0.49 & $1.20-3.80$ \\
Simple Knowledge & 3.03 & & \\
Seek single answers & 3.03 & 0.29 & $2.09-3.91$ \\
Certain Knowledge & 3.17 & & \\
Avoid ambiguity & 3.17 & 0.56 & $1.60-4.60$ \\
\hline
\end{tabular}

Pre-service science teachers' preferences for creating a constructivist learning environment.

The average total score of CLES was 116.34. If all the participants choose " 3 " for each item in the survey, their average expected total CLES score will be 90.00. Hence, since the average total CLES score (116.34) is higher than the average expected total CLES score (90.0), it can be concluded that the pre-service science teachers generally prefer more constructivist learning environments.

The descriptive statistics results also showed that the participants had the highest mean score for item $3(\mathrm{M}=4.56)$ belonging to the learning to learn subscale and the lowest mean score for item $7(\mathrm{M}=2.52)$ belonging to the learning to communicate subscale of CLES. Accordingly, pre-service science teachers stated that they would prefer their students to learn science as a part of their life outside of school (item 3). Moreover, they would prefer their students to learn that science cannot create perfect solutions to problems (item 7).

Pre-service science teachers' preferences more for creating a constructivist learning environment on the basis of the subscales of CLES.

In order to determine pre-service science teachers' preferences for creating a constructivist learning environment in their future classes, descriptive statistics was conducted. Table 7 shows the mean values for five factors of CLES. Based on the results, it can be concluded that the participants had 
numerically different mean scores for the five subscales. In other words, all participants had high mean scores in terms of the preferences for creating a constructivist learning environment for all the subscales of CLES because their mean scores were above 3.0. They prefer their students to learn to learn $(M=4.18)$, learn about the world $(M=4.14)$, and learn about science $(M=4.09)$ more than learn to speak out $(M=3.60)$, and learn to communicate $(M=3.39)$.

According to Table 7, the learning to learn subscale of CLES had the highest mean score while the learning to communicate subscale had the lowest one.

Table 7. Pre-service science teachers' mean scores on subdimensions of CLES

\begin{tabular}{lll}
\hline Subscales & M & SD \\
\hline Learning about the world & 4.14 & 0.79 \\
Learning about science & 4.09 & 0.73 \\
Learning to speak out & 3.60 & 0.90 \\
Learning to learn & 4.18 & 0.62 \\
Learning to communicate & 3.39 & 0.73 \\
\hline
\end{tabular}

The relationship between pre-service science teachers' epistemological beliefs and preferences for creating a constructivist learning environment.

Correlation analyses were conducted to investigate the relationship between epistemelogical beliefs and preferences. According to the results of the analyses, there is a small negative correlation between the pre-service science teachers' epistemological beliefs and preferences for creating a constructivist learning environment, $\mathrm{r}=-.14, \mathrm{n}=531, \mathrm{p}=.00$ (see Table 8). That is, the more sophisticated epistemological beliefs participants have, the higher scores they get in CLES.

Table 8. Correlations (Pearson r)

\begin{tabular}{lll}
\hline & Total score of CLES \\
\hline & Pearson Correlation & $-.140^{* *}$ \\
Total score of SEQ & Sig. (2-tailed) & .001 \\
& $\mathrm{~N}$ & 531 \\
\hline \multirow{2*}{*}{ Correlation is significant at the 0.01} & \\
level (2-tailed). &
\end{tabular}

Relationship between pre-service science teachers' epistemological beliefs and preferences for creating a constructivist learning environment on the basis of subscales.

Correlation analyses were conducted to investigate the relationship between the subscales of SEQ and those of CLES. Table 9 shows the Pearson correlation coefficients related to the subscales of SEQ and CLES. Small correlations were found between the CLES subscales and three subscales of SEQ, namely omniscient authority, innate ability and simple knowledge. Also, there was no statistically significant correlation between the CLES subscales and the certain knowledge subscale of SEQ. Thus, the results are discussed below basing on these three SEQ subscales.

Omniscient Authority versus CLES Subscales.

According to the results of the analyses, there is a small negative correlation between the omniscient authority subscale of SEQ and the learning to learn subscale of CLES, $r=-.22, n=531, p=.00$. This means, if participants do not believe in the omniscience of authority, they prefer their students to learn to learn. In other words, if participants prefer to teach in a student-centered manner in future courses, they will also prefer their students to be responsible for their own learning. Similarly, a small negative correlation was found between omniscient authority and learning about the world, $\mathrm{r}=-.18, \mathrm{n}$ $=531, \mathrm{p}=.00$. This means that as participants do not believe in the omniscience of authority, they will prefer their students to learn about the world. Additionally, a small negative correlation was found between omniscient authority and learning about science, $r=-.12, n=531, p=.01$. This means that as participants do not believe in the omniscience of authority, they will prefer their students to learn about science. On the other hand, a small positive correlation was found between omniscient authority and learning to communicate, $\mathrm{r}=.11, \mathrm{n}=531, \mathrm{p}=.02$. This means that if participants believe 
in the omniscience of authority, they will prefer their students to learn to communicate. In other words, if participants behave as a facilitator in their future lessons, they will allow their students to make discussions in the classroom.

Innate Ability versus CLES Subscales.

According to the results of the analyses, there is a small positive correlation between the innate ability subscale of SEQ and the learning to communicate subscale of CLES, $r=.11, n=531, p=.01$. This means that as participants believe learning is innate, they will prefer their students to learn to communicate. On the other hand, a small negative correlation was found between innate ability and learning to learn, $\mathrm{r}=-.13, \mathrm{n}=531, \mathrm{p}=.00$. This means that as participants believe learning is not innate, they will prefer their students to learn to learn. Additionally, a small negative correlation was found between innate ability and learning about the world, $\mathrm{r}=-.18, \mathrm{n}=531, \mathrm{p}=.00$. This means that as participants believe learning is not innate, they prefer their students to learn about the world. Lastly, a small negative correlation was found between innate ability and learning about science, $r=$ $.12, \mathrm{n}=531, \mathrm{p}=.01$. This means that, as participants believe learning is not innate, they will prefer their students to learn about science. In other words, if participants think learning is not innate, they will prefer their students to learn the properties of science, such as subjectivity.

Simple Knowledge versus CLES Subscales.

According to the results of the analyses, there is a small negative correlation between the simple knowledge subscale of SEQ and the learning to learn subscale of CLES, $r=-.10, n=531, p=.03$. This means that, as participants believe knowledge is not simple, they will prefer their students to learn to learn. Similarly, there is a small negative correlation between the simple knowledge subscale of SEQ and the learning about the world subscale of CLES, $\mathrm{r}=-.18, \mathrm{n}=531, \mathrm{p}=.00$. This means that, as participants believe knowledge is not simple, they will prefer their students to learn about the world. Thus, as they think knowledge is complex, they will expect their students to make a link between school science and their daily life experiences.

Table 9. Correlations (Pearson r)

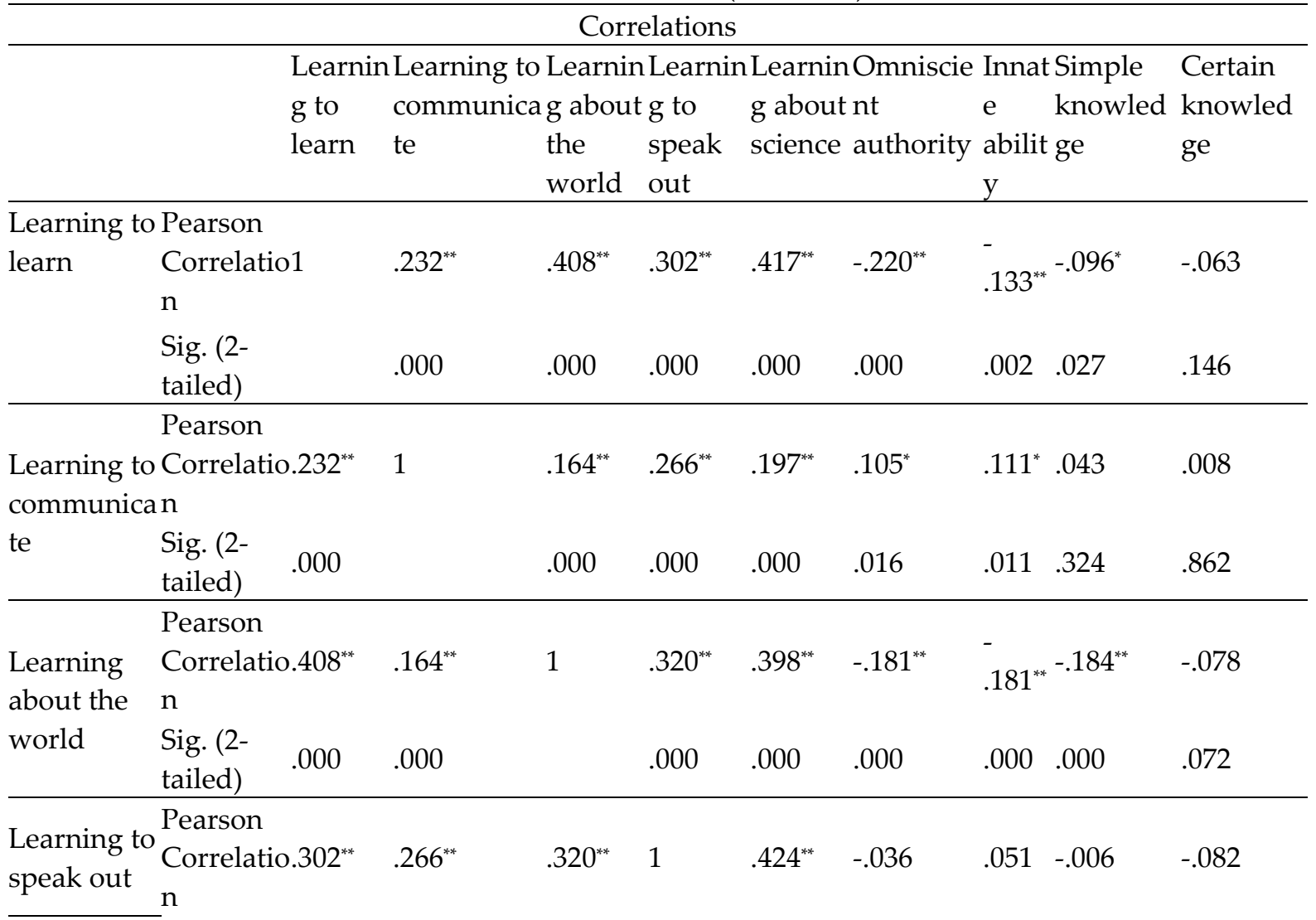




\begin{tabular}{|c|c|c|c|c|c|c|c|c|c|c|}
\hline & $\begin{array}{l}\text { Sig. (2- } \\
\text { tailed) }\end{array}$ & .000 & .000 & .000 & & .000 & .413 & .245 & .892 & .058 \\
\hline \multirow{2}{*}{$\begin{array}{l}\text { Learning } \\
\text { about } \\
\text { science }\end{array}$} & \multicolumn{2}{|c|}{$\begin{array}{l}\text { Pearson } \\
\text { Correlatio. } 417^{* *} \\
\mathrm{n}\end{array}$} & $.197^{* *}$ & $.398^{* *}$ & $.424^{* *}$ & \multirow[t]{2}{*}{1} & $-.123^{* * *}$ & $\begin{array}{l}- \\
.119^{* *}\end{array}$ & $-.094^{*}$ & $-.088^{*}$ \\
\hline & $\begin{array}{l}\text { Sig. (2- } \\
\text { tailed) }\end{array}$ & .000 & .000 & .000 & .000 & & .005 & .006 & .030 & .042 \\
\hline \multirow{2}{*}{$\begin{array}{l}\text { Omniscient } \\
\text { authority }\end{array}$} & \multicolumn{2}{|c|}{$\begin{array}{l}\text { Pearson } \\
\text { Correlatio- } .220^{* *} \\
\mathrm{n}\end{array}$} & $.105^{*}$ & $-.181^{* *}$ & -.036 & $-.123^{* *}$ & 1 & \multicolumn{2}{|c|}{$.361^{* *} .417^{* *}$} & $.218^{* *}$ \\
\hline & $\begin{array}{l}\text { Sig. (2- } \\
\text { tailed) }\end{array}$ & ,000 & .016 & .000 & .413 & .005 & & .000 & .000 & .000 \\
\hline \multirow{2}{*}{$\begin{array}{l}\text { Innate } \\
\text { ability }\end{array}$} & \multicolumn{2}{|c|}{$\begin{array}{l}\text { Pearson } \\
\text { Correlatio-, } 133^{* *} \\
n\end{array}$} & $.111^{*}$ & $-.181^{* *}$ & .051 & $-.119^{* *}$ & $.361^{* *}$ & 1 & $.304^{* *}$ & $.193^{* *}$ \\
\hline & $\begin{array}{l}\text { Sig. (2- } \\
\text { tailed) }\end{array}$ & ,002 & .011 & .000 & .245 & .006 & .000 & & .000 & .000 \\
\hline \multirow{2}{*}{$\begin{array}{l}\text { Simple } \\
\text { knowledge }\end{array}$} & $\begin{array}{l}\text { Pearson } \\
\text { Correlati } \\
\mathrm{n}\end{array}$ & o-.096* & .043 & $-.184^{* *}$ & -.006 & $-.094^{*}$ & $.417^{* *}$ & \multicolumn{2}{|c|}{$.304^{* *} 1$} & $.257^{*}$ \\
\hline & $\begin{array}{l}\text { Sig. (2- } \\
\text { tailed) }\end{array}$ & .027 & .324 & .000 & .892 & .030 & .000 & \multicolumn{2}{|l|}{.000} & .000 \\
\hline \multirow{2}{*}{$\begin{array}{l}\text { Certain } \\
\text { knowledge }\end{array}$} & \multicolumn{2}{|c|}{$\begin{array}{l}\text { Correlatio-.063 } \\
n\end{array}$} & .008 & -.078 & -.082 & $-.088^{*}$ & $.218^{* *}$ & $.193^{* *}$ & $.257^{* *}$ & 1 \\
\hline & $\begin{array}{l}\text { Sig. (2- } \\
\text { tailed) }\end{array}$ & .146 & .862 & .072 & .058 & .042 & .000 & .000 & .000 & \\
\hline
\end{tabular}

**. Correlation is significant at the 0.01 level (2-tailed).

*. Correlation is significant at the 0.05 level (2-tailed).

\section{Discussion}

\section{Epistemological beliefs.}

In the present study, the results revealed that the pre-service science teachers' scores from highest to lowest with respect to epistemelogical beliefs were as follows: Certain Knowledge ( $\mathrm{M}=3.17)$, Simple Knowledge ( $M=3.03)$, Innate Ability $(M=2.63)$, and Omniscient Authority $(M=2.11)$. Since the highest score represents relatively naive epistemological beliefs, these results can be interpreted as the pre-service science teachers mostly believe knowledge is certain and simple, and learning is innate while they mostly believe that authority is not superior. Therefore, the participants had a naive view in terms of certain knowledge, simple knowledge, and innate ability.

As the literature was examined in terms of the "Certain Knowledge" dimension, it was seen that the "Certain Knowledge" dimension had the highest mean score (Barzideh et al., 2012; de Juanas \& Beltrán, 2012; Eroğlu, 2009; Ismail et al., 2012; Perry, 1968, 1970).

Participants had naive beliefs on Simple Knowledge dimension and there are some other studies supporting this finding (e.g., Chan, 2004; Perry, 1968, 1970; Ravindran et al., 2005; Yılmaz-Tüzün \& Topçu, 2008, 2013).

The pre-service science teachers also had naive beliefs on Innate Ability dimension as supported by some other studies (Perry, 1968, 1970; Ravindran et al., 2005). 
The result of this study showed that preservice science teachers had relatively sophisticated epistemological beliefs in terms of the Omniscient Authority dimension. In parallel with this study, the findings of Findlan (2006), Ismail et al. (2012), Ogan-Bekiroğlu and Şengül-Turgut (2011), and Perry (1970) revealed that omniscient authority had the lowest mean score. On the other hand, Perry (1968) studied university students' omniscient authority beliefs and reported that students entered the university with less sophisticated epistemological beliefs in terms of omniscient authority. Also, Perry (1968) stated that university students developed more sophisticated beliefs in time in terms of omniscient authority. This development occurred in all dimensions of epistemological beliefs. In other words, at the end of their university education they started to believe that knowledge is complex, tentative, and acquired through reason and empirical evidence. Another study conducted by YilmazTüzün and Topçu (2008) revealed results on be half of omniscient authority dimension. According to results of their study, pre-service science teachers enter science education programs with certain experiences about teaching due to their previous learning experiences, and these experiences affect their professional development throughout teacher education programs. Yılmaz-Tüzün and Topçu (2008) stated that pre-service science teachers may have been subjected to traditional teaching strategies in Turkish educational system. This approach may have led students to understand that science is a knowledge discovered by scientists. Also, teachers can transmit this knowledge to students in this strategy. Hence, pre-service science teachers cannot reflect upon their scientific knowledge critically in their teaching environment. This may be a reason for pre-service science teachers' naive epistemological beliefs on omniscient authority in their study. In the present study, in contrast, pre-service science teachers had relatively sophisticated epistemological beliefs in terms of omniscient authority. The reason for this difference between the two studies may be due to the fact that constructivism is more integrated better now than it was in the year 2008.

One reason behind these findings of the present study may be the fact that participants were taught with a traditional-oriented approach until 2005. In the traditional-oriented approach, teaching is performed as a teacher-centered activity and students are passive in learning process. They only listen to their teachers and take notes (Taber, 2008). However, after 2005, constructivist approach has been considered in the national curriculum in Turkey. Thus, students have begun to change their beliefs especially on omniscient authority due to the effect of the constructivist approach since this subdimension of SEQ was consistently emphasized by teachers in Turkish educational system and teaching about science has performed as student-centered. Moreover, in Turkey, pre-service science teachers and teachers internalized that teachers are facilitator in the learning process. In a similar vein, according to Jaworska (2009), teachers should be facilitators rather than the omniscient authority in the constructivist teaching environment and help their students while constructing the knowledge. However, this internalization could not be reflected in their beliefs on certain knowledge, simple knowledge, and innate ability. Although, constructivist teaching strategies have been applied in the Turkish educational system since 2005, many teachers may still apply traditional teaching strategies in their classrooms. Therefore, pre-service science teachers may not have completely developed their epistemological beliefs yet.

\section{Constructivist learning environments.}

According to the results, learn to learn (LL) dimension of CLES had the highest mean value. This can be concluded that pre-service science teachers prefer their students to learn to learn. Also, the participants prefer their students in the future to learn about the world (LW) and learn about the science (LS). However, as indicated by the mean values (Table 7), both the learning to speak out (LSO) and learning to communicate (LC) subscales had lower values than those the mean value of the other subscales. Similarly LL, LW and LS had the three highest mean scores while LSO and LC had the lowest ones in the study of Barzideh et al. (2012). Since LS includes items about the nature of science, high scores may show the participants' adequate understanding of the nature of science (Lederman 2007). Similarly, Aydin et al. (2012) found that pre-service chemistry teachers had the highest score in the LSO subscale of CLES. Although, Aydin et al. (2012) found the lowest score in the LS, the scores on both their study and the present study were similar with respect to the subscales of CLES. The reason for the LC and LSO subscales' having low scores may be the fact that pre-service science teachers may have inadequate pedagogical and content knowledge in science. Therefore, they may not have adequate communication skills in terms of class management. In other words, the 
participants may prefer their students not to communicate with each other and the teacher in their future classes.

The relationship between epistemological beliefs and constructivist learning environments.

According to the results, pre-service science teachers generally have developing epistemological beliefs rather than having more sophisticated epistemological beliefs and they generally prefer more constructivist learning environments. Also, there was a small negative correlation between the participants' epistemological beliefs and preferences for creating a constructivist learning environment which means that the more sophisticated epistemological beliefs they have, the more constructivist learning environments they prefer. This result supports the finding of Tsai (2000). Similarly, Conley et al. (2004) found that students in constructivist learning environments developed more sophisticated epistemological beliefs than those in traditional classrooms. The study of Taylor and Fraser (1991) revealed that there were positive relationships between students' epistemological beliefs and preferences for constructivist learning environments. In the same study, it was also stated that students with more sophisticated epistemological beliefs generally preferred to learn in constructivist environments where they could interact with others, integrate their prior knowledge and experiences with the new constructed knowledge and control their learning activities. This relationship can be seen in Gunstone's (1991) study. According to Gunstone (1991), the perceptions of the learning environment of students represent their epistemological beliefs about what constitutes learning and how knowledge is created. For instance, in Gunstone's (1991) study, a high school student, who strongly asserted that science was a collection of proven facts and formulas, did not see any advantage in the constructivist teaching strategy even after he had really experienced it in a constructivist learning environment.

\section{The relationships between subscales of epistemological beliefs and constructivist learning environments.}

The results showed that although there were small correlations between the CLES subscales and the three subscales of SEQ (omniscient authority, innate ability and simple knowledge), there was no statistically significant correlation between the CLES subscales and the certain knowledge subscale of SEQ. In the same way, there was no statistically significant correlation between the learning to speak out and the subscales of SEQ.

Omniscient Authority and Learn to Learn.

According to the results of the analyses, if participants did not believe in the omniscience of authority, they preferred their students to learn to learn (LL) which means that pre-service science teachers preferred their students to make decisions regarding teaching, planning and assessing in their science classes.

Omniscient Authority and Learning to Communicate.

There was a statistically significant positive correlation between omniscient authority and learning to communicate (LC). Although, pre-service science teachers believed in the omniscience of authority, they preferred their students to negotiate with each other in the learning process. However, preservice science teachers had the lowest score in the LC. Hence, although participants are willing to allow their students to communicate in their classes in the present study, they do not have a tendency to tolerate negotiation among students in their future classes. Similarly, in the study of Özkal et al. (2009), the student negotiation dimension has a lower mean score than some other dimensions.

Omniscient Authority and Learning about the world.

According to the results, if participants do not believe the omniscience of authority, they prefer their students to learn about the world (LW). That means, as pre-service science teachers think authority is not omniscient, they prefer their students to relate science with the out of school experiences. This result is consistent with the study of Barzideh et al. (2012). There was a small negative correlation between omniscient authority and LW in the study of Barzideh et al. (2012). 
Omniscient Authority and Learning about Science.

According to the results, as participants do not believe the omniscience of authority, they prefer their students to learn about science (LS). In other words, as pre-service science teachers think the authority is not omniscient, they prefer their students to learn the properties of science such as subjectivity and tentativeness. Barzideh et al. (2012) also found a small negative correlation between omniscient authority and LS.

Innate Ability and Learning about the world.

There was a statistically significant negative correlation between innate ability (IA) and learning about world (LW). As participants believed learning is not innate, they preferred their students to learn about world. In other words, pre-service science teachers who believe learning is not innate are in favor of their students connecting science with out of school experiences. In keeping with this, in the study of Özkal (2007), it was found that students who believe knowledge is constructed from one's experiences and judgment and learning ability is not innate have constructivist conceptions of teaching and learning.

Innate Ability and Learning to Communicate.

Based on the data analysis results, it was found that participants who believe learning is innate prefer their students to learn to communicate. In other words, as pre-service science teachers believe the ability to learn is genetically predetermined, they let their students to negotiate and explain their ideas. Researchers interpreted this result as pre-service science teachers participated to the study having conservative life styles. Thus, they might think that learning is innate with the effect of their conservative frame of mind. They were also under the influence of constructivist teaching strategies and students might be active in the science lessons in terms of their view.

Innate Ability and Learning to Learn.

In the present study, it was found that as participants believe learning is not innate, they prefer their students to learn to learn which means as pre-service science teachers think ability to learn is genetically predetermined, they prefer their students to share the control of their learning process with the teacher. Barzideh et al. (2012) also found a small negative correlation between innate ability and LL.

Innate Ability and Learning about Science.

A small negative correlation was found between innate ability and LS. This means as participants believe the ability to learn is acquired through experience rather than being genetically predetermined, they prefer their students to learn the properties of science such as subjectivity and tentativeness.

Innate Ability and Learning to Speak Out.

There was not a statistically significant correlation between IA and learning to speak out (LSO). As participants believed learning is innate, they preferred their students to learn to speak out. In other words, participants who believe learning is not innate can question their environment or they can ask their teachers question about some classroom affairs.

Simple Knowledge and Learning to Learn.

According to the results, as participants believe knowledge is not simple, they prefer their students to learn to learn (LL). In other words, as pre-service science teachers think knowledge is complex rather than simple, they prefer their students to take the responsibility for their own learning. Supportively, Barzideh et al. (2012) also found a negative medium correlation between simple knowledge and LL. In addition to this, Chan (2004) stated that pre-service teachers who do not believe in the traditional concepts are likely to believe that knowledge is complex rather than simple. Hence, this finding of the present study is rational.

Simple Knowledge and Learning about the world.

According to the results, as participants believe knowledge is not simple, they prefer their students to learn about the world (LW). This result is parallel with the finding of study of Barzideh et al., (2012). 
In their study, Barzideh et al. (2012) found a negative medium correlation between simple knowledge and LW. In support of this, Schommer and Hutter (2002) suggested that epistemological beliefs have an effect on everyday life issues. They also revealed that people who have sophisticated epistemological beliefs in the simple knowledge dimension are more likely to be willing to modify their ideas about daily life issues.

Certain Knowledge and CLES Subscales.

The results of the present study revealed that there was no statistically significant correlation between CLES subscales and the certain knowledge subscale of SEQ. However, there was a negative correlation between certain knowledge and CLES subscales in some other studies (e.g. Barzideh et al., 2012; Chan, 2004). In these studies, it was stated that students who prefer to learn in traditional environments generally hold the belief that knowledge is certain.

\section{Implications}

In this study, it was aimed to explore the relationship between pre-service science teachers' epistemological beliefs and perceptions of a constructivist learning environment. However, there were some limitations to this study. For example, the structure equation modeling technique could be applied for data analysis in order to understand this relationship better. Also, more participants should be included in future studies to make more accurate generalizations regarding the results.

The present study has some important implications that should be taken into consideration by teachers, policy makers of pre-service science teacher education, pre-service teachers, curriculum developers and researchers interested in epistemological beliefs and constructivism.

Teachers play a major role in applying epistemological beliefs based on constructivist teaching strategies to the science curriculum. To allow teachers to apply these beliefs to science courses, they should be sufficiently trained as qualified to create constructivist learning environments in science classrooms effectively. Moreover, teachers should take their students' epistemological beliefs into consideration and try to enhance these beliefs. To do this, firstly, they should be informed about the meaning and importance of epistemological beliefs, and secondly, how to measure and develop students' epistemological beliefs in their classrooms. Additionally, researchers and policy makers should organize workshops and meetings in order to promote the epistemological beliefs of preservice teachers, teachers, and students. By doing these things, teachers should internalise constructivist teaching strategies like inquiry, hands-on activities, and project based learning to develop their students' epistemological beliefs.

The both in 2005 and 2013 Turkish elementary science and technology curricula are based on constructivist approach. However, these curricula might be insufficient in terms of epistemological beliefs. Therefore, curriculum developers should take this into consideration and rearrange the last curriculum on epistemological beliefs based on constructivist teaching strategies.

Instead of trying to keep students quiet and passive in the classroom, the teacher should enable them to communicate and utilize collaborative learning strategies. Moreover, teachers should facilitate their students to learn about the world, learn to speak out, learn about science, and learn to learn.

In order to investigate pre-service science teachers' epistemological beliefs and perceptions of constructivist learning environment deeper, further research - a qualitative or mixed method study could be conducted. Conducting interviews would develop a deeper understanding. Also an experimental study that feeds constructivism on epistemological beliefs could be planned and implemented.

In summary, epistemological beliefs and the constructivism approach together have an important role in science education. Hence, incorporation of a learning environment which involves feeding these two main factors into pre-service science teacher education programs would improve science education in Turkey. 


\section{References}

Aldridge, J. M., Fraser, B. J., and Taylor, P .C. (2000). Constructivist learning environments in a cross-national study in Taiwan and Australia. International Journal of Science Education, 22(1), 27-55.

Aydın, S., Boz, Y., Sungur, S., and Çetin, G. (2012). Examination of pre-service chemistry teachers' preferences for creating constructivist learning environment. Hacettepe University Journal of Education, 42, 36-47.

Aypay, A. (2011). The adaptation of the teaching-learning conceptions questionnaire and its relationship with epistemological beliefs. Educational Sciences: Theory and Practice, 11(1), 21-29.

Barzideh, O. A., Ghasemizad, A., Khajehei, H. and Motamed, H. (2012). The relationship among constructivist learning environment perception, epistemological beliefs, and academic achievement using structural equation model. Multidisciplinary Journal of Wulfenia, 19(10), 9-21.

Chan, K.-W. (2003). Hong Kong teacher education students' epistemological beliefs and approaches to learning. Research in Education, 69, 36-50.

Chan, K.-W. (2004). Preservice teachers' epistemological beliefs and conceptions about teaching and learning: cultural implications for research in teacher education. Australian Journal of Teacher Education, 29(1), 1-13.

Chan, K.-W. (2011). Preservice teacher education students' epistemological beliefs and conceptions about learning. Instructional Science, 39(1), 87-108.

Clark, L. A., and Watson, D. (1995). Constructing validity: Basic issues in objective scale development. Psychological Assessment, 7, 309-319.

Conley, A. M., Pintrich, P. R., Vekiri, I., and Harrison, D. (2004). Changes in epistemological beliefs in elementary science students. Contemporary Educational Psychology, 29, 186-204.

de Juanas, A., and Beltrán, J. A. (2012). Epistemological beliefs of students of pedagogy and sciences of the education. Revista de Psicodidáctica, 17(1), 1-15.

Elby, A., and Hammer, D. (2001). On the substance of a sophisticated epistemology. Science Education, 85, 554-567.

Findlan, C. H. (2006). A Mixed-method study of teachers' epistemological beliefs and reading instructional practices. ProQuest Information and Learning Company.

Fraenkel, J. R., and Wallen, N. E. (2009). How to design and evaluate research in education (7th ed.). San Francisco: McGraw-Hill.

Fraser, B. J., \& Rentoul, A. J. (1982). Relationships between school-level and classroom-level environment. The Alberta Journal of Educational Research, 28, 212-225.

Gunstone, R. F. (1991). Constructivism and metacognition: Theoretical issues and classroom studies. In: Duit, R., Goldberg, F., \& Niedderer, H. (Ed.), Research in Physics Learning: Theoretical Issues and Empirical Studies. Kiel, Germany: Institute of Science Education.

Hofer, B. K. (2001). Personal epistemology research: Implications for learning and teaching. Educational Psychology Review, 13, 353-383.

Hofer, B. K., and Pintrich, P. R. (1997). The development of epistemological theories: Beliefs about knowledge and knowing and their relation to learning. Review of Educational Research, 67(1), 88-140.

Ismail, W., Abedalaziz, N., Hussin, Z., Mohamed, M. F., and Saad, R. M. (2012). Epistemological beliefs of undergraduate students as function of gender and academic level. OIDA International Journal of Sustainable Development, 5(2), 109-118.

Jaworska, S. (2009). The German language in British higher education: Problems, challenges, teaching and learning perspectives (5th ed.). Fremdsprachen in Geschichte und Gegenwart, Harrassowitz, Wiesbaden.

Johnson, B., and McClure, R. (2004). Validity and reliability of a shortened, revised version of the constructivist learning environment survey. Learning Environments Research, 7, 65-80.

Jonassen, D. H. (1999). Designing constructivist learning environments. In C.M. Reigeluth, (Ed.). Instructional design theories and models: A new paradigm of instructional technology, Vol. 2 (pp. 215-240). Mahwah, NJ: Lawrence Erlbaum Associates.

Jonassen, D. H. (1991). Objectivism vs. constructivism: Do we need a new paradigm? Educational Technology: Research and Development, 39(3), 5-14.

Kardash, C. M., and Scholes, R. J. (1996). Effects of preexisting beliefs, epistemological beliefs and need for cognition on interpretation of controversial issues. Journal of Educational Psychology, 88(2), 260-271.

Krathwohl, D. R. (1998). Methods of educational and social science research: An integrated approach (2nd ed.). White Plains, New York: Addison Wesley Longman, Inc.

Lederman, N. G. (2007). Nature of Science: Past, present and future. In S. K. Abell, \& N. G. Lederman (Eds), Handbook of Research on Science Education, (pp.831 -879). New Jersey: Lawrence Erlbaum Associates.

Lee, S. S., and Fraser, B. J. (2000). The Constructivist learning environment of science classrooms in Korea. The annual meeting of the Australasian Science Education Research Association, Western Australia.

Liang, L. L. and Gabel, D. L. (2005). Effectiveness of a constructivist approach to science instruction for prospective elementary teachers. International Journal of Science Education, 27(10), 1143-1162.

Limon, M. (2001). On the cognitive conflict as an instructional strategy for conceptual change: a critical appraisal. Learning and instruction, 11, 357-380.

Oxford, R. (1997). Constructivism: Shape-shifting, substance, and teacher education applications. Peabody Journal of Education, 72(1), 35-66.

Özkal, K. (2007). Scientific epistemological beliefs, perceptions of constructivist learning environment and attitude towards science as determinants of students approaches to learning. (Unpublished master's thesis). Middle East Technical University, Ankara, Turkey.

Özkal, K., Tekkaya, C., and Çakıroğlu, J. (2009). Investigating $8^{\text {th }}$ grade students' perceptions of constructivist science learning environment. Education and Science, 34(153), 38-46.

Pallant J. (2007). SPSS survival manual: A step by step guide to data analysis using SPSS. Buckingham: Open University Press.

Perry, W. G. (1968). Patterns of development in thought and values of students in a liberal arts college: A validation of a scheme. (Report No. 5-0825). Cambridge, MA: Bureau of Study Counsel, Harvard University. 
Perry, W. G. (1970). Forms of intellectual and ethical development in the college years: A scheme. New York: Holt, Rinehart \& Winston.

Ravindran, B., Greene, B. A., and Debacker, T. K. (2005). Predicting preservice teachers' cognitive engagement with goals and epistemological beliefs. Journal of Educational Research, 98(4), 222-233.

Saylan, A. (2014). Relationships among pre-service science teachers' epistemological beliefs, knowledge level and trustworthiness on information sources: climate change, nuclear energy, and organ donation and transplantation (Unpublished master's thesis). Middle East Technical University, Ankara, Turkey.

Schommer, M. (1990). Effects of beliefs about the nature of knowledge on comprehension. Journal of Educational Psychology, 82, 498-508.

Schommer, M. (1993). Epistemological development and academic performance among secondary schools. Journal of Educational Psychology, 85(3), 406-411.

Schommer, M. (1994). Synthesising epistemological belief of research tentative understandings and provocative confusions. Educational Psychology Review, 6(4), 293-319.

Schommer, M., and Hutter, R. (2002). Epistemological beliefs and thinking about everyday controversial issues. Journal of Psychology, 136(1), 5-20.

Sheppard, C., and Gilbert, J. (1991). Course design, teaching method and student epistemology. Higher Education, 22, 229-249.

Taber, K. S. (2001). Shifting sands: a case study of conceptual development as competition between alternative conceptions. International Journal of Science Education, 23(7), 731- 753.

Taber, K. S. (2008). Exploring student learning from a constructivist perspective in diverse educational contexts. Journal of Turkish Science Education, 5(1), 2-21.

Taylor, P., and Fraser, B. (1991). CLES: An instrument for assessing constructivist learning environments. The National Association for Research in Science Teaching, The Abbey, Fontane, Wisconsin.

Taylor, P., Fraser, B. J., and Fisher, D. L. (1997). Monitoring constructivist classroom learning environments. International Journal of Educational Research, 27, 293-302.

Tsai, C. C. (2000). Relationships between student scientific epistemological beliefs and perceptions of constructivist learning environments. Educational Research, 42(2), 193-205.

Wilson, B. (Ed.) (1996). Constructivist learning environments: Case studies in instructional design. New Jersey: Educational Technology Publications.

Windschitl, M. (2002). Framing constructivism in practice as the negotiation of dilemmas: an analysis of the conceptual, pedagogical, cultural, and political challenges facing teachers. Review of Educational Research, 72(2), 131-175.

Yager, R. E. (1991). The constructivist learning model. The Science Teacher, 56(6), 52-57.

Yılmaz-Tüzün Ö., and Topçu, M. S. (2008). Relationships among preservice science teachers' epistemological beliefs, epistemological world views, and self-efficacy beliefs. International Journal of Science Education, 30(1), 65-85.

Yılmaz-Tüzün Ö., and Topçu, M. S. (2010). Investigating the relationships among elementary school students' epistemological beliefs, metacognition, and constructivist science learning environment. Journal of Science Teacher Education, 21, 255-273.

Yılmaz-Tüzün Ö., and Topçu, M. S. (2013). Exploration of preservice science teachers' epistemological beliefs, world views, and self-efficacy considering gender and achievement. Elementary Education Online, 12(3), 659-673.

Zeidler, D. L., Osborne, J., Erduran, S., Simon, S., and Monk, M. (2003). The role of argument during discourse about socioscientific issues. In D. L. Zeidler (Ed.), The role of moral reasoning and discourse on socioscientific issues in science education (pp. 97-116). Dordrecht: Kluwer Academic Publishers. 